\title{
Is Intraoperative Ultrasound Required in Cervical Spinal Tumors? A Prospective Study
}

\author{
Intraoperatif Ultrason Servikal Spinal Tümörlerde Gerekli midir? \\ Prospektif Bir Çalışma
}

Zafer O. TOKTAS ${ }^{1}$, Soner SAHIN ${ }^{2}$, Orkun KOBAN ${ }^{3}$, Mehmet SORAR ${ }^{4}$, Denız KONYA ${ }^{1}$

${ }^{1}$ Marmara University, Institution of Neurological Sciences, Department of Neurosurgery, Istanbul, Turkey

${ }^{2}$ Kocaeli Derince Research and Teaching Hospital, Department of Neurosurgery, Kocaeli, Turkey

${ }^{3}$ Haseki Research and Teaching Hospital, Department of Neurosurgery, Istanbul, Turkey

${ }^{4}$ Diskapi Research and Teaching Hospital, Department of Neurosurgery, Ankara, Turkey

Corresponding Author: Zafer O.TOKTAS / E-mail: drzafertoktas@mynet.com

ABSTRACT

AIM: To determine the role of intraoperative ultrasonography (IOUSG) in the surgical management of patients with intradural spinal tumors.

MATERIAL and METHODS:Twenty-six patients with intradural spinal cord tumors were surgically treated under intraoperative ultrasonographic guidance between January 2007 and May 2011. Guidance with IOUSG was used in 26 patients, of which 14 fourteen had extramedullary and 12 had intramedullary tumors. Intraoperative ultrasound assistance was used to localize each tumor exactly before opening the dura. The extent of tumor resection was verified using axial and sagittal sonographic views. The extent of tumor resection achieved with IOUSG guidance was assessed on postoperative early control MRI sections.

RESULTS: Total tumor resection was achieved in 22 (84\%) of 26 cases. All of the residual tumors were typically intramedullary and infiltrative. The sensitivity of IOUSG for the determination of the extent of resection was found to be $92 \%$. Ultrasonography was found to be effective in identification of tumor boundaries and protection of spinal cord vessels. The average time spent for IOUSG assessment was 7 minutes.

CONCLUSION: Intraoperative ultrasonography is practical, reliable and highly sensitive for spinal cord surgery. It not only enhances surgical orientation, but also reduces morbidity and helps to resect the tumor completely.

KEYWORDS: Intraoperative, Ultrasonography, Spinal cord, Tumor

ÖZ

AMAÇ: İntradural spinal tümörlü hastaların cerrahi yönetiminde intraoperatif ultrasongrafinin rolünün belirlenmesidir.

YÖNTEM ve GEREÇLER: Ocak 2007-Mayıs 2011 tarihleri arasında intraoperatif ultrasonografi rehberliğinde cerrahi olarak tedavi edilmiş intradural spinal kord tümörlü 26 hasta çalışmamıza dahil edilmiştir. 26 hastanın 14'ü ekstramedüller, 12'si ise intramedüller yerleşimliydi. Her bir tümör için dura açılmadan önce intraoperatif ultrasonografi kullanıldı. Tümör rezeksiyonunun genişliği aksiyel ve sagittal ultrasonografik görüntüler yardımıyla belirlendi. IOUSG rehberliğinde gerçekleştirilen tümör rezeksiyonunun genişliği postoperatif erken MR kesitleriyle değerlendirildi.

BULGULAR: 26 olgunun 22'sinde (\%84) total tümör çıkarımı sağlandı. Rezidüel tümörlerin tümü intramedüller ve infiltratif vasıflıdı. Tümör rezeksiyonunun genişliğinin belirlenmesinde IOUSG'nin duyarlılığı \%92 olarak bulundu. Ultrasonografi'nin tümör sınırlarının belirlenmesinde ve spinal kord damarlarının korunmasında etkili olduğu bulundu. IOUSG değerlendirilme zamanı ortalama 7 dakikaydı.

SONUÇ: Spinal kord cerrahisinde IOUSG pratik, güvenilir ve yüksek duyarlılı̆̆a sahip bir yöntemdir. Cerrahi oryantasyonu arttırmamasına karşın morbiditenin azaltılması ve tümörün tam olarak çıkarılmasına yardımcı olmaktadır.

ANAHTAR SÖZCÜKLER: İntraoperatif, Ultrasonografi, Spinal kord, Tümör

\section{INTRODUCTION}

Surgical procedures undertaken to treat spinal tumors may be difficult to perform because several complex anomalies often occur together and because long segments of the spine may be involved. Since the clinical outcome depends on the proper identification, localization, and correction of all such abnormalities, it is desirable to image the spinal canal and its contents during surgery $(4,7)$.
The concept of intraoperative imaging is still evolving and image-guided surgery is gaining popularity in the field of neuro-oncology. Ongoing advances yield progression in tumor treatment for neurosurgeons $(10,14)$. A significant advance in spinal surgery has been made possible by the recent use of real-time sonography in the operating room, a technique that allows the surgeon to monitor the progress of surgery, to extend the procedure as the disease dictates, and 
to ensure as complete a correction as possible before closure $(5,6)$.

Neuro-oncologic surgery mainly aims for tumor removal while saving the surrounding vital neural tissue. Since spinal cord function is highly vulnerable to surgical manipulation, intraoperative image guidance might be beneficial. This study aims to assess the efficacy and practicality of intraoperative ultrasonography (IOUSG) for the surgical treatment of spinal cord tumors.

\section{MATERIAL and METHODS}

This prospective study was performed in the neurosurgery department of Marmara University Neurosurgical Sciences institution. A total of 33 cases with intradural spinal tumors were surgically treated between January 2009 and May 2011. Intraoperative ultrasonographic findings were recorded in 26 patients consisting of 15 males and 11 females with a mean age of 54 (19-73). Numbers of intra and extramedullary tumors in this series were 12 and 14 respectively (Table I).

Preparation and Intraoperative Ultrasonography Technique

Preoperative diagnosis was based on MRI studies and decisions for necessary laminectomy levels were made according to the extension of each lesion. All patients were operated by a posterior midline approach in the prone position. Motorevoked potentials (MEP) were routinely monitored. In order to prevent inadequate laminectomies, the extent of bone removal was justified by referral to anatomic landmarks and fluoroscopic and ultrasonographic guidance. Additive laminectomies were made where indicated.

Intraoperative sonographic images were obtained by a single round-tip $2 \mathrm{~cm}$ linear transducer probe (Mindray DC3, 6CV1 probe, Shenzen, China) draped for sterility with ultrasonic gel at the tip (Figure 1A, B). To obtain initial IOUSG images, the surgical cavity was filled with saline after the first level of laminectomy. The fluid filled cavity formed a clear acoustic window and eliminated the risk of dural compression by probe manipulation. Dural incisions were tailored according to the underlying pathology as visualized by IOUSG. Sonographic images were recorded in sagittal and axial planes. Doppler mode was used for monitoring spinal cord vessels where necessary. Additional time spent on IOUSG was noted. Tumor resections were carried out until total resection was confirmed with both microscopic findings and IOUSG.

\section{Evaluation of IOUSG Sensitivity}

All patients were examined with contrast-enhanced highfield MRI before and after surgery. Ultrasonographic findings were compared with MRI studies (regarded as gold standard) by a radiologist blinded to the study. Correlations between MRI and IOUSG images were addressed. MRI intensity and sonographic echogenity were compared. A specificity value for IOUSG was determined.

\section{RESULTS}

\section{Obtaining the Ultrasonographic View}

Ultrasonography was able to visualize the lesion successfully in all of the cases. The time spent for IOUSG assessment was 7 minutes in average (range: 2-15) depending on the localization and size of the tumor.

We found that an almost total (at least one level) laminectomy was essential to obtain a clear exposure. Surgical cavities were filled with saline to obtain a good sonographic window. Ligamentum flavum, facet joints, gelfoam, blood and air bubbles blocked ultrasound beams and caused artifacts in the sonogram. A laminectomy wide enough to acquire images in both sagittal and axial planes was performed. Laminectomy led to the expansion of the dural sac and IOUSG views may help the discrimination of the dura-tumor relationship and identification of the exact layout for (intradural, extramedullary etc.) for some neoplasms preoperatively (Figure 2A-F). This benefit was more prominent especially for lesions ventral to the spinal cord. In case of obvious vessel compression, Doppler mode provided additional information on the local blood flow.

\section{Contribution to Surgical Technique}

The IOUSG visualization provided real-time images prior to tumor resection in all cases. Dural incisions were tailored totally according to IOUSG. The IOUSG-guided dural opening was appropriate in all of the 26 cases. According to IOUSG findings, additional bone removal was indicated in 4 of 26 cases (15\%) before the dural incision was made.

In 25 out of 26 cases (96.1\%), there was no sign of an underlying tumor before dural incision was made to assure the correct

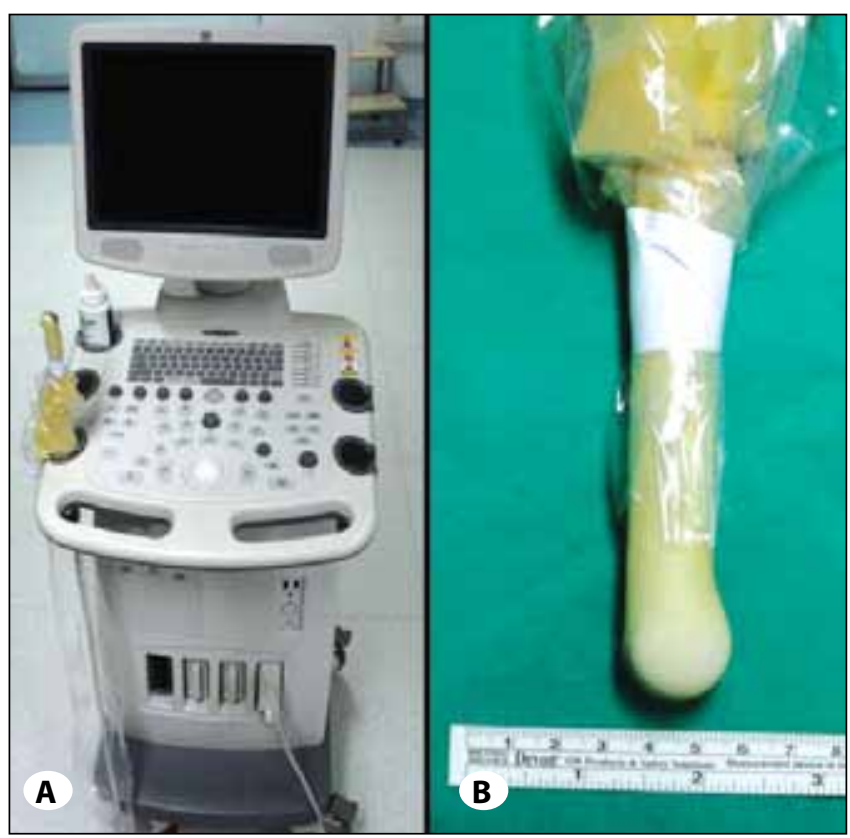

Figure 1: A) The ultrasound device used for IOUSG; B) Probe tip prepared for surgical use. 
Table I: Clinical and Radiological Data of the Cases Comprising Our Series

\begin{tabular}{|c|c|c|c|c|c|c|c|c|}
\hline Case & $\begin{array}{c}\text { Level } \\
\text { of } \\
\text { lesion }\end{array}$ & $\begin{array}{l}\text { Dura-cord } \\
\text { relevance }\end{array}$ & Tumor type & $\begin{array}{l}\text { Residual } \\
\text { as } \\
\text { assessed } \\
\text { by USG }\end{array}$ & $\begin{array}{l}\text { Residual } \\
\text { as } \\
\text { assessed } \\
\text { by MRI* }\end{array}$ & $\begin{array}{c}\text { Post- } \\
\text { operative } \\
\text { additional } \\
\text { neurologic } \\
\text { deficit }\end{array}$ & $\begin{array}{c}\text { Time } \\
\text { spent } \\
\text { on USG } \\
\text { (minutes) }\end{array}$ & $\begin{array}{l}\text { Sonographic } \\
\text { echogeneity }\end{array}$ \\
\hline 1 & $\mathrm{C} 3$ & $\begin{array}{l}\text { Extramedullary } \\
\text { ventral, }\end{array}$ & meningioma & $(-)$ & $(-)$ & None & 6 & high \\
\hline 2 & C3-4 & intramedullary & astrocytoma & $(-)$ & $(+)$ & $\begin{array}{c}\text { numbness } \\
\text { in left arm, } \\
\text { ataxia }\end{array}$ & 11 & iso \\
\hline 3 & C4 & $\begin{array}{l}\text { Eextramedullary, } \\
\text { lateral }\end{array}$ & schwannoma & $(-)$ & $(-)$ & none & 3 & low \\
\hline 4 & C5-6 & intramedullary & ependymoma & $(-)$ & $(-)$ & none & 5 & mixed \\
\hline 5 & $\mathrm{C} 5$ & intramedullary & cavernoma & $(-)$ & $(-)$ & none & 2 & mixed \\
\hline 6 & C5 & $\begin{array}{l}\text { Extramedullary, } \\
\text { lateral }\end{array}$ & schwannoma & $(-)$ & $(-)$ & none & 2 & high \\
\hline 7 & C5 & $\begin{array}{l}\text { Extramedullary } \\
\text { dorsal, }\end{array}$ & meningioma & $(-)$ & $(-)$ & none & 5 & high \\
\hline 8 & C6-7 & intramedullary & astrocytoma & $(+)$ & $(+)$ & $\begin{array}{c}\text { Gait ataxia, } \\
\text { numbness } \\
\text { in lower } \\
\text { extremity }\end{array}$ & 13 & low \\
\hline 9 & $\mathrm{C7}$ & intramedullary & hemangioblastoma & $(-)$ & $(-)$ & none & 7 & high $^{* *}$ \\
\hline 10 & C7-T1 & $\begin{array}{l}\text { Extramedullary, } \\
\text { lateral }\end{array}$ & meningioma & $(-)$ & $(-)$ & none & 3 & high \\
\hline 11 & $\mathrm{~T} 1$ & intramedullary & cavernoma & $(-)$ & $(-)$ & none & 5 & low \\
\hline 12 & $\mathrm{~T} 1$ & $\begin{array}{l}\text { Extramedullary, } \\
\text { dorsal }\end{array}$ & meningioma & $(-)$ & $(-)$ & none & 7 & high \\
\hline 13 & $\mathrm{~T} 2-3$ & intramedullary & astrocytoma & $(-)$ & $(-)$ & ataxia & 12 & low \\
\hline 14 & $\mathrm{~T} 2-3$ & intramedullary & hemangioblastoma & $(-)$ & $(-)$ & none & 8 & $\operatorname{High}^{* *}$ \\
\hline 15 & T3 & intramedullary & ependymoma & $(-)$ & $(-)$ & none & 10 & high \\
\hline 16 & T3-4-5 & Extramedullary & metastasis & $(-)$ & $(-)$ & none & 15 & iso \\
\hline 17 & $\mathrm{~T} 4$ & Extramedullary & schwannoma & $(-)$ & $(-)$ & none & 4 & iso \\
\hline 18 & T5-6 & Extramedullary & meningioma & $(-)$ & $(-)$ & $\begin{array}{c}\text { Lower limb } \\
\text { deficit }\end{array}$ & 12 & high \\
\hline 19 & T6-7 & intramedullary & hemangioblastoma & $(-)$ & $(-)$ & none & 11 & $\mathrm{High}^{* *}$ \\
\hline 20 & T7 & Extramedullary & meningioma & $(-)$ & $(-)$ & none & 6 & high \\
\hline 21 & T9 & $\begin{array}{l}\text { Extramedullary, } \\
\text { dorsal }\end{array}$ & meningioma & $(-)$ & $(-)$ & none & 3 & high \\
\hline 22 & T9-10 & intramedullary & ependymoma & $(+)$ & $(+)$ & $\begin{array}{l}\text { Lower limb } \\
\text { deficit, } \\
\text { ataxia, } \\
\text { urinary } \\
\text { retention }\end{array}$ & 14 & high \\
\hline 23 & $\mathrm{~T} 11$ & Extramedullary & schwannoma & $(-)$ & $(-)$ & none & 3 & iso \\
\hline 24 & L1 & $\begin{array}{l}\text { intramedullary, } \\
\text { conal }\end{array}$ & epidermoid & $(-)$ & $(+)$ & none & 4 & low \\
\hline 25 & $\mathrm{~L} 2$ & Extramedullary & schwannoma & $(-)$ & $(-)$ & none & 3 & high \\
\hline 26 & L2-3 & Extramedullary & lipoma & $(-)$ & $(-)$ & none & 4 & high \\
\hline
\end{tabular}

(Hints: * presence of tumor remnant as assessed by postoperative contrast enhanced MRI study; **Hyperechogenic tumor nodule and less echogenic cystic component. 
laminectomy level. In almost all cases, laminectomy levels had to be confirmed by IOUSG and the dura was opened only after sonographic confirmation. In 2 of 26 cases $(7.7 \%$, both ventral to the cord), the lesion was not exposed even after dural opening. Navigation to these tumors was made possible by IOUSG.

Intraoperative ultrasonography was more time-consuming in intramedullary tumors than in extramedullary tumors (Table I). In two cases of astrocytoma, IOUSG revealed hypoechoic residual tumors which were undetectable by microscopic view. Microscopic discrimination between surrounding edema and tumor tissue was difficult in some intramedullary tumors. Intraoperative ultrasonography was helpful in deciding the extent of resection in these circumstances.

\section{Sensitivity of IOUSG and Relevance to MRI}

The ultrasonic survey failed to detect the residual tumor in cases 2 and 24 on Table I (false negativity). Those residual tumors were clearly visualized in MRI controls. All sonographic conclusions for tumor residuals were compared with MRI studies, and the overall sensitivity value for IOUSG in assessing tumor resection was 92\% (please note that MRI controls were taken as the 'gold standard'). Intraoperative ultrasonography was completely accurate for confirmation of the total resection particularly for extramedullary lesions.

Comparison of MRI findings to IOUSG also revealed a correlation between the tumors' intensity in T2 weighted images and echogenity on IOUSG. Lesions that were

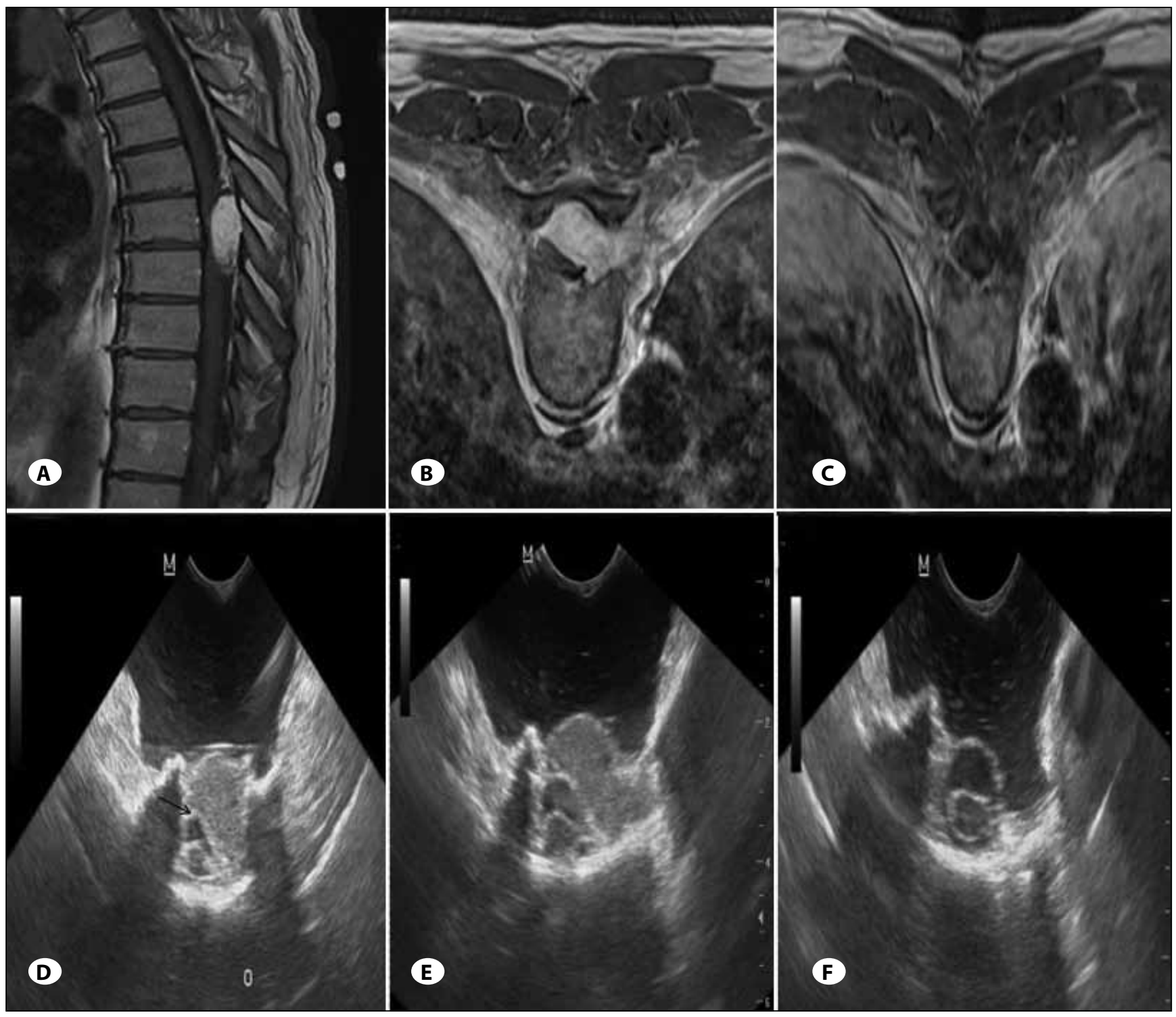

Figure 2: A-B) Preoperative T1-weighted contrast-enhanced MRI sections of a mid-thoracal lesion compressing the spinal cord. Note that discrimination of the tumor's exact layout (intradural vs extradural) is difficult in preoperative MRI. C) Postoperative MRI control. D-E) IOUSG views after laminectomy and facetectomy show expansion of the dural sac, decompression of the spinal cord and the dural layer clearly (black arrow indicates dura) F) Final IOUSG view after total tumor resection. 
hypointense on $\mathrm{T} 2$ images represented hyper-echogenity on IOUSG (Figure $3 A, B$ ), and vice versa. Tumors with high lipid content such as epidermoids and lipomas were exceptional in this aspect.

According to postoperative MRI studies, 22 out of 26 tumors $(84 \%)$ in our series were totally resected. Three of those residues were intentional ( 1 epidermoid carcinoma, 1 astrocytoma, 1 ependymoma) due to adherence to the spinal cord or impaired MEP values. In the other single case, IOUSG failed to visualize the residual astrocytoma which was revealed in the postoperative MRI study (Figure $4 \mathrm{~A}-\mathrm{H}$ ). That residual tissue was also imperceptible in microscopic operative view.

\section{DISCUSSION}

Tumors in the spinal cord or within the spinal canal are operated either to remove the mass totally, to obtain a biopsy for tissue diagnosis, or to relieve a partial decompression of the spinal cord (4-6). During these procedures, it is often difficult for the surgeon to visualize the mass or to assess the progress of surgery, particularly when the mass is within the spinal cord or when the mass is ventral in location after a laminectomy. Ultrasonography may aid in elimination of many of these problems owing to its ability to image the entire spinal canal and its contents intraoperatively $(7,10)$.

In intramedullary tumors, IOUSG can identify the level of maximum cord enlargement especially when there is little evidence of a swollen cord at surgery. A single microsurgical biopsy at the site identified by IOUSG may be enough to establish a tissue diagnosis and obviate multiple violations of the spinal cord tissue. Thereby, the area of spinal cord parenchymal disruption is limited and the potential neurologic complications of a spinal cord biopsy may be avoided.

Identifying the interface between normal spinal cord tissue and an intramedullary mass is important if an attempt to remove the tumor is to be made. The normal spinal cord is composed of low-level echoes with highly reflective surfaces, and a linear central echo exists within the cord. Disturbance of these appearances (slightly increased echogenicity of the cord, total anechoic area within the cord, loss of central echo, and loss of highly reflective surfaces of the cord) suggest an intramedullary process $(5,6)$. These abnormalities are not specific for intramedullary tumors, since some of these changes can also be seen spinal cord injuries (6).

When complete tumor removal is targeted, the desired limits of surgery need to be outlined. By the virtue of IOUSG, not only the possibility of leaving unsuspected tumor behind or removal of normal tissue beyond the boundaries of the tumor will be reduced, but also the chance of missing the proper level of tumor will be decreased. If no sonographic abnormalities are observed at the level of operation, widening of the laminectomy by a segment either inferiorly or superiorly may reveal a mass, which might have otherwise been skipped. Intraoperative ultrasonography can be used to detect a small hematoma or collection of fluid occurring at the site of spinal cord biopsy $(6,7)$.

Appropriate exposure of the surgeon to an extramedullary mass depends on the approach. Ventrally located masses may be hidden by the spinal cord or thecal sac after the laminectomy. In these circumstances, IOUSG can demonstrate the exact location and size of the mass, without necessity for retraction of the cord or thecal sac or without any bone or softtissue resection $(4,5)$. This advantage facilitates more rapid and complete tumor resection and decompression of spinal cord can be further assessed with repeated IOUSGs. Masses that seem to be located in the extradural space on preoperative radiographic views may turn out to have an intradural component on surgical inspection after a laminectomy $(4,7)$. Without IOUSG, this type of tumor extension may be skipped resulting in inadequate removal.

Intraoperative ultrasonography may show that bony decompression is not enough to relieve the pressure on the upper cervical spinal cord in some circumstances $(6,7)$. Opening the dura and application of a dural graft to relieve
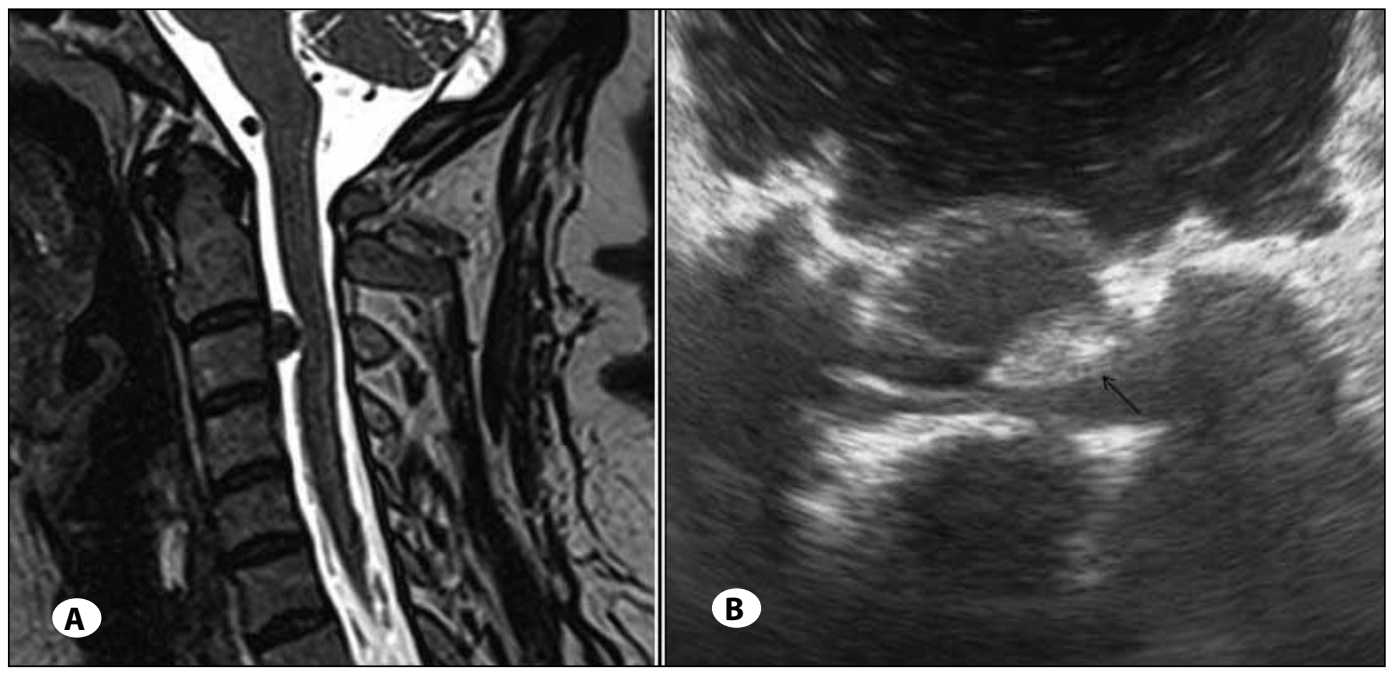

Figure 3:

A) Preoperative $\mathrm{T} 2$ weighted MRI of a meningioma at $\mathrm{C} 3$ level. The lesion is ventrally seated and hypointense on MRI. B) Intraoperative USG view shows the lesion is hyper-echogenic. 

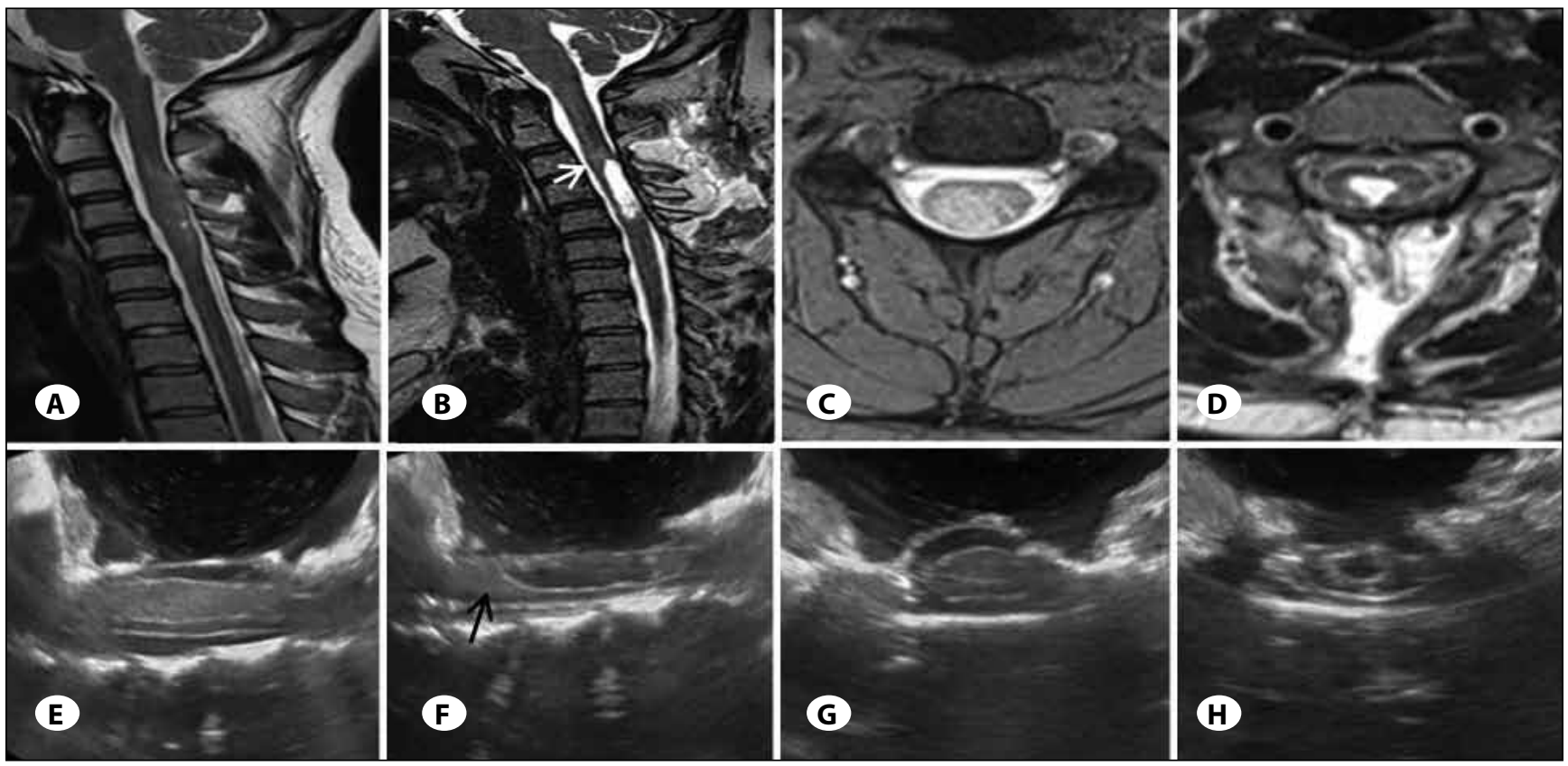

Figure 4: A-C) Preoperative T2 weighted sagittal and axial sections of a cervical astrocytoma. B-D) Postoperative control MRI images. Tumor residual is shown in sagittal view (white arrow). E-G) IOUSG views in sagittal and axial planes before tumor resection. F-H) IOUSG views after tumor resection. Note that, the remnant shown by MRI is not exactly demonstrated by IOUSG (black).

the compression on the spinal cord may be performed under guidance of IOUSG. Extramedullary masses tend to have high ecogenicity and they can be easily distinguished from the normal hypoechoic spinal cord tissue. In contrast, the intramedullary masses are only slightly different form the normal cord tissue in terms of echogenicity $(6,10,14)$.

MRI and CT can also be used as intraoperative imaging modality, but they are expensive, bulky and unsuitable for real-time visualization $(2,14)$. Intraoperative MRI imaging of a prone-positioned patient is even more difficult and inspiratory motion artifacts are unavoidable (12). Our experience shows that IOUSG offers greater practicality since ultrasound is readily ambulatory, less time-consuming and relatively cheaper. There is no need for patient transportation to the device and it is applicable in almost all posterior spinal cord approaches without specific preparation.

High image resolution and quality contribute to excellence in intraoperative imaging. Advances in ultrasound devices have increased picture quality in recent years, but inadequate device settings may spoil the resolution. High frequency transducer probes (10 MHz and more) are recommended for superficial tissues ranging from $0.5 \mathrm{~cm}$ to $4 \mathrm{~cm}$ depth but higher frequency results in poor penetration to deeper tissue $(8,9)$. Multi-frequency probes can deliver altered frequency ranging from $3 \mathrm{MHz}$ to $12 \mathrm{MHz}$ and seem more convenient for intraoperative use. We used a multi-frequency probe and a 5-8 MHz frequency interval for this study. The size of the probe is also important. Smaller probe tips are more practical in IOUSG (13).
Intraoperative ultrasonography provides tissue images in axial and sagittal -but not in coronal- sections. Dural sac, spinal cord, anterior spinal artery, cerebrospinal fluid (CSF), disc spaces and tumors can all be identified depending on their variations in echogenity. Kanetaka have suggested that IOUSG can be sensitive enough to detect CSF flow in and out of spinal arachnoid cysts (3). Ultrasound is constitutionally capable of setting apart cystic from solid, and hypoechogenic from hyperechogenic structures, thereby facilitating discrimination of tumors from neural tissue. If MRI is considered as the gold standard for spinal cord imaging; IOUSG may be defined as complementary equipment. Yet, the high sensitivity rate proposed by this study may encourage frequent use of IOUSG during resection of spinal cord tumors. Previous studies have shown a correlation between intraoperative MRI and IOUSG for brain lesions, but MRI was reserved as a reference technique $(1,11)$.

MRI can sometimes fall short of defining whether a spinal tumor is intradural or extradural. This is especially true for large lesions, which cause extensive cord compression and when subarachnoidal space has diminished. We wish to emphasize that IOUSG is very efficient in assessing a lesion's relation to the spinal cord and dural sac, especially when the lamina is removed, the dural sac has expanded and a gap between cord and dura has occurred. At this stage, IOUSG gives the chance to revise the surgical plan, prevent inadequate dural opening and customize bone removal when necessary. The only alternative method to offer such a benefit is intraoperative spinal MRI, which is a rather troublesome technique (1). IOUSG can also prevent further tissue damage and any neurologic 
deficit caused by dissections while searching for the tumor (8). During this study, we observed clear Doppler images of spinal intradural arteries and veins.

Limitations of IOUSG are disturbance of vision by blood, haemostatic materials and air bubbles. A clear sonographic view can be obtained only after sufficient bone removal. Some iso-echogenic lesions may be disguised as neural tissue and as shown in our study, total removal of some intramedullary tumors is still challenging. However, the high rate of IOUSG sensitivity detected in this study encourages for its prospective use.

\section{CONCLUSION}

Intraoperative ultrasonography is a cheap, practical and highly sensitive method that aids in spinal cord tumor surgery. It not only helps for surgical orientation, but also minimizes iatrogenic cord trauma and helps to achieve better outcomes. Therefore, we recommend its routine use in spinal cord tumor surgery.

\section{REFERENCES}

1. Bernays RL: Intraoperative imaging in neurosurgery. $M R I, C T$, ultrasound. Introduction Acta Neurochir Suppl 85:1-3, 2003

2. Hosoda T, Takeuchi H, Hashimoto N, Kitai R, Arishima H, Kodera T, Higashino Y, Sato K, Kikuta K: Usefulness of intraoperative computed tomography in surgery for low-grade gliomas: A comparative study between two series without and with intraoperative computed tomography. Neurol Med Chir (Tokyo) 51:490-495, 2011

3. Kanetaka M, Sugita S, Chikuda H, Takeshita K, Ono T, Oshima Y, Kawaguchi $\mathrm{H}$, Nakamura K: Use of Doppler ultrasonography to detect an elusive communication of a spinal extradural arachnoid cyst. J Clin Neurosci 18:863-864, 2010

4. Montalvo BM, Quencer RM: Intraoperative sonography in spinal surgery: Current state of the art. Neuroradiology. 28:551-590, 1986
5. Quencer RM, Montalvo BM: Normal intraoperative spinal sonography. AJR Am J Roentgenol 143:1301-1305, 1984

6. Quencer RM, Montalvo BM, Green BA, Eismont FJ: Intraoperative spinal sonography of soft-tissue masses of the spinal cord and spinal canal. AJR Am J Roentgenol 143: 1307-1315, 1984

7. Quencer RM, Montalvo BM, Naidich TP, Post MJ, Green BA, Page LK: Intraoperative sonography in spinal dysraphism and syringohydromyelia. AJR Am J Roentgenol 148:1005-1013, 1987

8. Regelsberger J, Langer N, Fritzsche E, Westphal M: Intraoperative ultrasound of intra and extramedullary tumours. Ultraschall Med 24:399-403, 2003

9. Reinacher PC, van Velthoven V: Intraoperative ultrasound imaging: Prac-tical applicability as a real-time navigation system. Acta Neurochir Suppl 85:89-93, 2003

10. Tjardes T, Shafizadeh S, Rixen D, Paffrath T, Bouillon B, Steinhausen ES, Baethis H: Image-guided spine surgery: State of the art and future directions. Eur Spine J 19:25-45, 2010

11. van Velthoven V: Intraoperative ultrasound imaging: Comparison of patho- morphological findings in US versus $\mathrm{CT}, \mathrm{MRI}$ and intraoperative findings. Acta Neurochir Suppl 85:95-99, 2003

12. Witkamp TD, Vandertop WP, Beek FJ, Notermans NC, Gooskens RH, van Waes PF: Medullary cone movement in subjects with a normal spinal cord and in patients with a tethered spinal cord. Radiology 220:208-212, 2001

13. Woydt M, Krone A, Soerensen N, Roosen K: Ultrasound-guided neuronaviga- tion of deep-seated cavernous haemangiomas: Clinical results and navigation techniques. $\mathrm{Br} J$ Neurosurg 15:485-495, 2001

14. Young RJ, Brennan N, Fraser JF, Brennan C: Advanced imaging in brain tumor surgery. Neuroimaging Clin N Am 20:311-335, 2010 